\title{
Pengalaman Traumatik Penyebab Gangguan Jiwa (Skizofrenia) Pasien di Rumah Sakit Jiwa Cimahi
}

\author{
Iyus Yosep, Ni Luh Nyoman Sri Puspowati, Aat Sriati \\ Bagian Keperawatan Jiwa \\ Fakultas Ilmu Keperawatan Universitas Padjadjaran, Bandung
}

\begin{abstract}
Abstrak
Salah satu faktor penyebab yang menjadi stresor seseorang mengalami gangguan jiwa adalah pengalaman traumatik. Pengalaman traumatik tersebut sulit dilupakan dan memiliki efek psikologis dalam waktu yang panjang. Apabila seseorang tidak mampu beradaptasi dalam menanggulangi stresor, maka akan timbul keluhan-keluhan dalam aspek kejiwaan, berupa gangguan jiwa ringan hingga berat. Salah satu bentuk gangguan jiwa yang paling banyak dan terus meningkat adalah gangguan jiwa berat yaitu skizofrenia. Tujuan penelitian ini adalah untuk memperoleh gambaran mengenai pengalaman traumatik pasien skizofrenia. Metode yang digunakan dalam penelitian ini adalah metode kualitatif dengan pendekatan fenomenologi. Populasi dalam penelitian ini adalah pasien skizofrenia yang dirawat di Rumah Sakit Jiwa Cimahi, subjek diperoleh berdasarkan purposive sampling sebanyak tujuh orang, pada bulan November 2008. Teknik pengumpulan data dilakukan dengan cara wawancara secara mendalam (in depth interview). Hasil penelitian terhadap pengalaman traumatik tujuh pasien skizofrenia menunjukkan adanya lima tema yang muncul yaitu: cita-cita/keinginan tak tercapai/kegagalan, kehilangan orang yang dicintai, kehilangan pekerjaan, orangtua galak/pola asuh otoriter, dan mendapat tindakan kekerasan. Terungkapnya pengalaman tersebut, memberi informasi bagi tim kesehatan dalam mencegah dan mengatasi meningkatnya pasien skizofrenia, khususnya yang diakibatkan oleh pengalaman traumatik yang dapat menjadi pencetus, sehingga angka kejadian skizofrenia dapat ditekan seminimal mungkin. [MKB. 2009;41(4):194-200].
\end{abstract}

Kata kunci: Pengalaman traumatik, skizofrenia, stresor

\section{Traumatic Experiences of Mental Disorder Client (Schizophrenia) at Mental Health Hospital Cimahi}

\begin{abstract}
One factor causes as stressor of mental health disorder was traumatic experiences that experiences never forgotten and psychological long lasting effect. Whenever anyone could not be adaptation to fight the stressor, there will suffer light and state symptom in mental disorder as a manifestation. One kind of chronic mental health disorder is schizophrenia. The purpose of this research was to find out description about schizophrenic client traumatic experiences. The method of this research was qualitative method with phenomenological approach. The population of this research was schizophrenic client covering with purposive sampling. Amount of informants in this research was seven persons. Each of sample include 4 mans and 3 women's. Technical of data collecting used by in dept interview. The result of traumatic experiences from seven schizophrenic client showed that there was 5 theme: failed of dream/failed to reach the life goals, loss of significant persons, jobless, sadism parent/pattern of authoritarian parenting and abused experience. Based on the result of that experiences give information for health provider team to prevent and implementation of schizophrenic client, especially for schizophrenic which caused by traumatic experiences. So that the occurrence of schizophrenia number which triggered by traumatic experience can be depressed as minimum as possible. [MKB. 2009;41(4):194-200].
\end{abstract}

Key words: Traumatic experiences, schizophrenia

Korespondensi: Iyus Yosep, S.Kp., M.Si, Bagian Keperawatan Jiwa Fakultas Ilmu Keperawatan Universitas Padjadjaran, Jln. Raya Bandung Sumedang KM 21 Jatinangor 45363, Hp. 081394665577 


\section{Pendahuluan}

Skizofrenia adalah gangguan mental yang sangat berat sehingga sebagian besar penderitanya tidak dapat pulih kembali seperti kondisi sebelum mereka mengalaminya. Skizofrenia berasal dari kata schizos yang berarti pecah-belah/bercabang, sedangkan fhren artinya jiwa. Istilah tersebut menjelaskan adanya perpecahan pikiran, emosi, dan perilaku pada pasien dengan gangguan tersebut. Secara umum pasien skizofrenia tidak mampu membedakan antara fantasi dan realita.

Skizofrenia adalah gangguan mental yang cukup serius dan berdampak luas, di Indonesia sebanyak 99\% pasien di RS Jiwa adalah penderita skizofrenia. Dari catatan Rekam Medik RS Jiwa Cimahi diperoleh data, bahwa pasien yang dirawat di RS Jiwa Cimahi sekitar 89,7\% adalah klien dengan diagnosis medis skizoprenia. ${ }^{1}$

Hal luar biasa dari penyakit skizofrenia ini adalah tidak hanya menghancurkan kondisi fisik dan psikologis klien, tetapi membawa kerusakan pada sendi-sendi keluarga dan masyarakat. Di negara maju skizofrenia disebut dengan killer of the young people dikarenakan skizofrenia dapat menghancurkan produktivitas kaum muda, karena biasanya muncul pada usia 16-30 tahun.

Permasalahannya banyak keluarga yang belum mengerti benar skizofrenia itu, sehingga ketidak mengertian itu melahirkan jalan pintas yang biasa dilakukan oleh keluarga yang memiliki klien skizofrenia. Biasanya keluarga melakukan tindakan seperti pemasungan, pengurungan, atau menyingkirkan klien skizofrenia. Tindakan yang dilakukan oleh keluarga tersebut sebenarnya dapat memperburuk kondisi klien skizofrenia. Kondisi seperti ini dapat memicu konflik dalam keluarga dan merupakan suatu stresor yang sangat besar bagi keluarga dan membuat keluarga harus mengerahkan segala sumberdaya yang dimiliki untuk mengatasinya. Suhu emosi dalam keluarga akan meningkat dan penanganan klien dalam waktu yang lama, serta dapat menguras ketahanan keluarga itu sendiri. Hal seperti ini banyak dijumpai di kalangan masyarakat sekitar kita.

Penelitian tentang pengalaman traumatik yang dirasakan pasien sebelum ia mengalami schizofrenia sangatlah penting, karena tingginya angka kekambuhan gangguan jiwa yang tidak diketahui stresor penyebabnya yaitu sekitar $60 \%$. Penelitian ini dapat menggali aspek pengalaman traumatik yang dialami. Pengalaman traumatik dapat mengawali dan mengantarkan pasien pada suatu kondisi terguncangnya kejiwaan yang ditandai dengan kesulitan membedakan antara fantasi dan realita, terputus dari relasi sosialnya, mengamuk, berbicara kasar, merusak, membakar bahkan sampai membunuh. Penelitian terhadap pengalaman traumatik dapat memberikan informasi penting sehingga kita dapat memberikan intervensi yang tepat serta pengenalan dan pencegahan sejak dini munculnya skizofrenia. Biaya besar yang dikeluarkan pemerintah dapat ditekan bila sejak dini kita mendapatkan informasi potensi yang dapat menjadi pemicu skizofrenia, diantaranya adalah pengalaman traumatik pasien.

\section{Metode}

Fenomenologi adalah bentuk penelitian kualitatif yang mencoba memberikan suatu informasi yang mendalam serta mengembangkan pemahaman tentang pengalaman hidup. Untuk memahami pengalaman traumatik pasien skizofrenia, dan metode fenomenologi memfasilitasi eksplorasi pengalaman hidup manusia yang dilihat dari sudut pandang individu yang diteliti.

Desain ini sangat tepat digunakan untuk menggali pengalaman traumatik pasien skizofrenia di Rumah Sakit Jiwa Cimahi, pengalaman ini menghasilkan karakteristik yang berbeda antara satu individu dan individu yang lain karena pengaruh dan faktor pengalaman sebelumnya, pendidikan, usia dan tingkat kedewasaan, konflik keluarga, dan lain-lain. Penentuan untuk jumlah informan atau nara sumber dalam penelitian ini didasarkan pada tercapainya tingkat kejenuhan data. Pengalaman traumatik yang ingin diperoleh adalah pengalaman traumatik yang bermakna dan mendalam sehingga menimbulkan gangguan jiwa (skizofrenia). Oleh karena itu, subjek penelitian ini adalah pasien yang mengala-mi skizofrenia di Rumah Sakit Jiwa Cimahi.

Teknik pengumpulan data dengan wawancara yang mendalam (in dept interview) dalam bentuk pertanyaan terbuka (open ended question). Maka pedoman interview dibuat sebagai acuan agar wawancara tidak keluar dari apa yang akan digali dan pertanyaan bersifat tidak terstruktur serta tidak mengikat sehingga setiap pertanyaan dapat dikembangkan sesuai dengan apa yang diutarakan oleh informan. Wawancara dapat dilakukan tidak terstruktur secara mendalam terhadap pasien. 
Untuk memperoleh keterangan lebih banyak, peneliti juga melakukan wawancara dengan perawat di ruang rawat inap, dan dokter yang merawat, serta melihat catatan pada rekam medik pasien. Mempelajari dokumen medis yang berkaitan dengan pasien dari nara sumber yang dapat dipercaya. Proses wawancara dilakukan pada pasien sesuai dengan kontrak yang telah disepakati. Instrumen utama yang digunakan selama wawancara adalah peneliti sendiri dengan bantuan tape recorder. Proses wawancara yang dilakukan peneliti sebanyak tiga kali pertemuan. Sebelumnya peneliti mencoba menjalin hubungan prapenelitian selama satu minggu untuk membina trust (saling percaya) maka pasien lebih terbuka. Peneliti juga membuat catatan yang bertujuan untuk mendokumentasikan keadaan/situasi saat berlangsungnya wawancara dan semua respons nonverbal yang ditunjukkan oleh informan. Hal ini ditujukan untuk membantu peneliti agar dapat merencanakan pertanyaan baru berikutnya serta membantu untuk mencari pokok penting dalam wawancara. Dalam penelitian ini juga peneliti memberikan kesempatan yang seluas-luasnya pada informan dalam menjawab pertanyaan yang diajukan dan peneliti juga berusaha mendorong informan supaya menceritakan pengalamannya secara terbuka.

Analisis data dilakukan sesuai pendekatan menurut Giorgi yang meliputi tahapan-tahapan analisis data. ${ }^{3}$ Mendengarkan hasil wawancara yang telah direkam kemudian peneliti membuat suatu transkrip wawancara untuk masing-masing informan guna memperoleh pemahaman secara keseluruhan dari data yang terkumpul. Membaca transkrip secara berulang untuk memperoleh pemahaman menyeluruh pada isi transkrip yang telah dibuat. Mengidentifikasi tema yang muncul dari setiap transkrip tersebut. Mengelompokkan, serta menjelaskan pertanyaan yang relevan dan mengandung tema yang muncul. Menerangkan tema yang muncul dengan isi dari keseluruhan hasil wawancara. Menuliskan tema yang muncul dan mengilustrasikan sesuai pernyataan informan. Melakukan validasi dengan cara menyampaikan tema yang muncul kepada informan yang bersangkutan.

\section{Hasil}

Dari hasil wawancara mendalam sebanyak 3 kali kepada tujuh orang informan, semua informan sebelum mengalami gangguan jiwa pernah mengalami kegagalan mencapai keinginannya. Semua informan menyatakan bahwa munculnya perasaan sakit hati yang mendalam dan sulit dilupakan. Informan pertama menggambarkan setelah gagal mencapai peringkat terbaik di kelas saat SMP menjadi murung dan sangat kecewa. Informan kedua mengalami kegagalan berulang saat melamar pekerjaan yang menyebabkan perasaan frustrasi dan menyalahkan diri sendiri. Informan ketiga muncul gejala sulit tidur, cemas gelisah setelah gagal untuk menjadi ABRI. Informan keempat muncul gejala gangguan jiwa setelah gagal mempertahankan pekerjaannya di hotel karena PHK. Informan kelima muncul gejala gangguan jiwa setelah gagal mempertahankan hubungan dengan pacar karena tidak mau diajak menikah. Informan kelima mengalami perasaan gagal dalam mencapai cita-cita sebagai TKW akibat terjebak penipuan, pelecehan seksual, dan pemerasan. Informan keenam muncul gangguan jiwa pertama kali karena memilki pengalaman yang sangat menyakitkan yaitu setelah gagal meyakinkan adiknya bahwa ia adalah kakak kandungnya asli. Informan terakhir merasa gagal diterima di keluarga dan diperlakukan tidak adil karena sering disuruh-suruh, dan diperlakukan berbeda, serta menjadi sasaran anggota keluarga lain dalam melakukan tugas-tugas di rumah.

Berdasarkan hasil penelitian, dari ketujuh informan yang diwawancarai, terdapat enam orang informan yang mengalami kehilangan orang yang dicintai, seperti yang diungkapkan oleh informan di bawah ini. Informan pertama merasakan pengalaman traumatik yang sulit dilupakan yaitu pada saat kehilangan istrinya dan anaknya setelah bercerai. Istrinya meminta cerai padahal ia masih sangat mencintainya. Perasaan kehilangan menjadi sulit dilupakan, terutama pada anaknya yang dibawa istrinya. Informan kedua merasakan pengalaman traumatik yang sulit dilupakan stelah istrinya meninggal karena penyakit kanker, yang paling sulit dilupakan adalah saat teringat bahwa menikah belum genap satu tahun sudah harus berpisah dengan istrinya. Informan ketiga menyampaikan perasaan traumatiknya adalah pada saat kehilangan ibu yang sangat dicintainya. Setelah kematian ibunya ia merasa putus asa, merasa terpukul, dan sering melamun karena merasa hanya ibunya yang paling mengerti hidupnya. Informan keempat 
lyus Yosep: Pengalaman Traumatik Penyebab Gangguan Jiwa (schizofrenia)

Tabel Stresor Bersifat Traumatik pada Pasien Skizofrenia

\begin{tabular}{cccccc}
\hline Informan & \multicolumn{5}{c}{ Stresor bersipat traumatik } \\
\cline { 2 - 6 } & $\begin{array}{c}\text { Cita-cita/ } \\
\text { Keinginan Tak } \\
\text { Tercapai, } \\
\text { Kegagalan }\end{array}$ & $\begin{array}{c}\text { Kehilangan } \\
\text { Orang yang } \\
\text { Dicintai }\end{array}$ & $\begin{array}{c}\text { Kehilangan } \\
\text { Pekerjaan }\end{array}$ & $\begin{array}{c}\text { Orangtua } \\
\text { Galak/Pola Asuh } \\
\text { Otoriter }\end{array}$ & $\begin{array}{c}\text { Mendapat Tindakan } \\
\text { Kekerasan }\end{array}$ \\
\hline 1 & $\sqrt{ }$ & $\sqrt{ }$ & $\sqrt{ }$ & - & - \\
2 & $\sqrt{ }$ & $\sqrt{ }$ & - & - & - \\
3 & $\sqrt{ }$ & $\sqrt{ }$ & $\sqrt{ }$ & - & - \\
4 & $\sqrt{ }$ & $\sqrt{ }$ & - & - & $\sqrt{ }$ \\
5 & $\sqrt{ }$ & - & $\sqrt{ }$ & $\sqrt{ }$ \\
6
\end{tabular}

merasa kehilangan orang yang dicintai setelah tiga tahun pacaran, ia harus mengakhiri hubungannya karena tidak disetujui orangtua. Sejak saat itu sering melamun dan muncul perasaan takut pada wanita dan tidak mau memikirkannya. Informan kelima sangat tertutup dan sulit untuk mencapai trust meskipun peneliti berupaya menjalin trust sejak pertemuan pertama sampai interaksi terakhir. Informasi traumatik berupa kehilangan orang yang dicintai didapatkan setelah melakukan wawancara mendalam dengan kakak pasien. Pasien merasa sangat sedih, bicara dan mulai tertawa sendiri setelah kehilangan suaminya yang pergi tanpa kabar dan berita. Pasien baru menikah beberapa bulan terus ditinggalkan oleh suaminya. Pada informan keenam memiliki pengalaman traumatik berupa kehilangan orang yang dicintai yaitu suaminya meninggal. Setelah suaminya meninggal, mulai muncul gejala tidak mau keluar rumah, melamun, tidak mau melakukan apa-apa, sampai akhirnya bicara dan tertawa sendiri.

Dari hasil wawancara kepada tujuh orang informan, terdapat lima orang informan yang mengalami kehilangan pekerjaan. Pada Informan pertama mengalami pengalaman traumatik berupa PHK dari pabrik. Ia dan istrinya mendapatkan pengalaman tersebut dua tahun setelah menikah. Setelah PHK pasien mulai murung dan tidak mau makan sampai muncul gejala-gejala gangguan jiwa. Informan kedua mengalami pengalaman traumatik berupa pemutusan hubungan kerja yang diikuti pemutusan hubungan dengan pacarnya akibat tidak punya pekerjaan lagi, stresor tersebut telah menekan pasien sampai tidak bisa tidur dan terus bersedih. Informan ketiga merasakan ketegangan yang sangat sulit untuk dikendalikan, gangguan harga diri, dan perasaan tak berguna setelah tiga tahun bekerja mendapatkan SK untuk pensiun muda. Informan keempat merasakan pengalaman traumatik seperti merasa hancur, kecewa, menangis, ingin kembali ke tanah air, trauma melihat surat kabar, dan merasa menderita saat terpaksa harus kehilangan pekerjaan yang didambakan menjadi TKW sukses di luar negeri. Sedangkan pada Informan kelima menyatakan memiliki pengalaman traumatik saat bekerja di Bali bekerja dengan teman tetapi diperlakukan seperti pembantu, harus mengerjakan semua hal. Akhirnya keluar dan harus kehilangan pekerjaan.

Dari tujuh informan yang diteliti, ada dua informan yang mengungkapkan pernah memiliki pengalaman traumatik yang sulit dilupakan berkaitan dengan orangtuanya. Informan pertama mengungkapkan ibunya yang galak, dan sering memarahi, serta banyak melarang. Selain hal tersebut kakaknya juga sering memukul sampai berdarah, pasien menjadi tidak betah di rumah dan sering ingin pergi keluar rumah. Informan kedua mengatakan bahwa bapaknya otoriter, setiap pembicaraan harus diikuti, dan bila tidak dituruti pasien dipukul.

Dari tujuh informan yang diteliti, terdapat tiga orang informan yang mendapat tindakan kekerasan. Menurut hasil wawancara mendalam dengan informan pertama tersirat data bahwa pasien pernah memilki pengalaman traumatik saat bertengkar dan dipukul oleh kakaknya. Hal lain yang sangat sulit dilupakan adalah saat bekerja di Kuwait mendapat kekerasan seperti dipukul, ditendang, dan dibanting. Pengalaman tersebut sulit dilupakan karena merasa diperlakukan seperti binatang. Menurut hasil wawancara mendalam dengan informan kedua tersirat data bahwa pasien pernah memilki pengalaman traumatik saat teringat bahwa ibunya galak. Sejak kecil sering dimarahi, dan sering dipukul, serta hidung sampai 
berdarah, Pada informan ketiga mengungkapkan pengalaman traumatik karena bapaknya galak dan otoriter serta sering memukul.

\section{Pembahasan}

Salah satu faktor yang menyebabkan terjadinya gangguan jiwa skizoprenia adalah pengalaman traumatik. Pengalaman traumatik tersebut sangat sulit dilupakan dan berpotensi memunculkan gejala awal gangguan jiwa. Berdasarkan hasil penelitian yang dilakukan kepada tujuh informan, didapatkan lima tema yang muncul yaitu: citacita/keinginan tak tercapai, kegagalan; kehilangan orang yang dicintai; kehilangan pekerjaan; orangtua galak/pola asuh otoriter; dan mendapat tindakan kekerasan.

Cita-cita/keinginan tak tercapai bagi sebagian orang dapat merupakan pengalaman traumatik, karena permasalahan yang dihadapi tidak dapat diatasi oleh yang bersangkutan, dan dapat merupakan sumber stres. Apabila yang bersangkutan tidak mampu beradaptasi dengan kondisi seperti ini,lama kelamaan orang tersebut akan mengalami frustrasi, dan akhirnya apabila kondisi tersebut tidak segera ditangani maka akan mengalami gangguan jiwa. Tidak semua orang mampu untuk menyelesaikan konflik yang dialaminya sehingga membuat orang tersebut jatuh dalam frustrasi yang mendalam dan lama kelamaan akan jatuh sakit (mengalami gangguan jiwa skizoprenia). ${ }^{4}$

Kegagalan informan dalam mewujudkan citacita/keinginanya adalah merupakan pengalaman traumatik bagi klien, maka pengalaman tersebut menjadi stresor yang sampai saat ini masih membekas, dan sulit untuk dilupakan, serta merupakan faktor penyebab informan mengalami gangguan jiwa skizofrenia. ${ }^{5}$ Seperti diungkapkan oleh Soewadi. ${ }^{7}$ Faktor-faktor yang mempengaruhi terjadinya gangguan jiwa yaitu masa kanak-kanak yang tidak menyenangkan, sering mengalami kegagalan, kehidupan yang penuh agresif, dan lingkungan yang tidak kondusif(bising, padat).

Faktor psikososial merupakan salah satu faktor yang menimbulkan gangguan jiwa. Stresor psikososial itu di antaranya adalah kehilangan orang yang dicintai, merasa gagal dalam bekerja, ketakutan terhadap penyakit yang dideritanya, dan kesemuanya itu merupakan stresor internal, berbagai masalah di dalam perkawinan, hubungan percintaan merupakan salah satu faktor stres psikososial yang dapat menjadi sumber stres yang dialami oleh seseorang. Misalnya pertengkaran, perpisahan, perceraian, dan kematian salah satu pasangan, serta ketidaksetiaan. ${ }^{8}$

Dari pengalaman yang diungkapkan oleh salah satu informan, bahwa kegagalan dalam membina rumah tangga, disebabkan kurangnya penghargaan terhadap pasangannya, dan adanya ketidakjujuran dari pasangannya. Oleh sebab itu kegagalan dalam membina jalinan kasih saat pacaran dikarenakan ketidakmampuan informan untuk membangun rumah tangga dan tidak adanya motivasi dari pasangan saat informan kehilangan pekerjaan, justru setelah informan di PHK malah ditinggalkan. Kondisi tersebut merupakan stresor yang tidak dapat diatasi oleh para informan, sehingga kondisi tersebut mengantarkan mereka kepada kondisi sakit (gangguan jiwa skizofrenia).

Stresor kehidupan yang dapat menimbulkan gangguan jiwa adalah stres pascatrauma. Kondisi ini biasanya disebabkan oleh bencana alam, huruhara, peperangan, kebakaran, kekerasan fisik, kekerasan emosional, kekerasan seksual, kehilangan orang yang dicintai, kehilangan pekerjaan, cita-cita tak tercapai, dan lain-lain. ${ }^{9}$

Pengalaman traumatik mengguncang keseimbangan tubuh dan jiwa, menstimulasi neurotransmiter dan biokimiawi tubuh mendesakkan diri dalam ingatan, maka menyebabkan peristiwa lain yang terjadi sehari-hari, pengalaman-pengalaman bahagia dan menyenangkan terpinggirkan dan seolah-olah tak penting, yang menguasai ingatan dan pikiran adalah pengalaman traumatik.

Maka sebaliknya apabila seseorang memiliki kematangan dalam pertumbuhan, akan mampu bertahan dan tetap stabil menghadapi kehilangan. Kehilangan kedekatan seseorang terhadap orang lain yang dianggap penting (significant person) merupakan kehilangan yang mencakup kejadian nyata/khayalan, seperti kasih sayang, kehilangan orang yang berarti, fungsi fisik, dan harga diri. Banyaknya situasi kehilangan dianggap sangat berpengaruh karena memiliki makna yang tinggi. Dapat pula mencakup kehilangan teman lama, kenangan yang indah, dan tetangga yang baik. Kemampuan seseorang untuk bertahan, tetap stabil dan bersikap positif terhadap kehilangan, itu suatu tanda kematangan dan pertumbuhan.

Dari hasil penelitian ini didapatkan ungkapan informan yang menyebabkan terguncangnya keseimbangan tubuh dan jiwa, pengalaman yang dialami informan adalah kehilangan orang yang 
dicintai, baik itu ibu, istri, anak, kekasih, dan mereka tidak memiliki kematangan dalam pertumbuhan, sehingga mereka tidak mampu bertahan/beradaptasi saat menghadapi kehilangan.

Kehilangan pekerjaan merupakan salah satu faktor penyebab seseorang mengalami gangguan jiwa. Masalah pekerjaan dapat merupakan sumber stres pada diri seseorang, bila tidak dapat diatasi yang bersangkutan dapat jatuh sakit. Misalnya kehilangan pekerjaan (PHK), pensiun (post power syndrome), pekerjaan terlalu banyak, pekerjaan tidak cocok, mutasi jabatan, dan lain-lain. Hal ini bergantung kepada bagaimana individu memaknai pengalaman yang dialami. ${ }^{10}$

Berdasarkan hasil penelitian maka didapatkan ungkapan informan bahwa pekerjaan merupakan kebanggaan bagi informan. Maka berdasarkan pengalaman yang dialami oleh informan, karena kehilangan pekerjaan, dia pun harus kehilangan orang yang dicintainya yaitu kekasihnya. Bahkan terjadi ketegangan peran, yang tadinya memiliki pekerjaan tiba-tiba di PHK, sehingga mengalami frustasi. Karena kondisi seperti itu tidak segera ditangani akhirnya dia pun mengalami gangguan jiwa skizofrenia.

Loss (kehilangan) merupakan ketegangan peran berhubungan dengan hilangnya peran atau posisi yang diharapkan dan individu mengalaminya sebagai frustrasi. Maka kondisi seperti ini merupakan stresor bagi mereka yang tidak segera ditanggulangi, sehingga akhirnya mereka pun jatuh dalam kondisi sakit yaitu gangguan jiwa mulai dari ringan sampai berat (skizofrenia). ${ }^{10}$

Pola asuh orangtua yang keras/pola asuh yang otoriter merupakan salah satu faktor predisposisi yang mengakibatkan gangguan jiwa. Ketidaklenturan (non resiliences) jiwa seseorang, akan memudahkan dirinya mengalami gangguan. ${ }^{11}$ Dalam mencegah gangguan jiwa diperlukan pola asuh yang baik (autoritative) sehingga dari mulai kanak-kanak sudah dibiasakan untuk bisa menyelesaikan masalah sendiri, tidak dependen (bergantung) pada orang lain. ${ }^{12}$

Hubungan yang ditandai dengan kurangnya sifat pengasuhan, komunikasi yang buruk, kurangnya batasan antara generasi, dan perasaan terjebak, semua terlibat dalam terjadinya gangguan jiwa. Salah satu faktor penting penyebab gangguan jiwa adalah karena salah dalam pengasuhan (pattern of parenting) hubungan yang patologis di antara anggota keluarga. ${ }^{13}$

Dari hasil penelitian diperoleh data yang diungkapkan oleh salah satu informan, bahwa orangtua informan memberikan pola asuh yang otoriter, sejak kecil informan memiliki sifat pendiam, tidak berani membantah (tidak bisa melakukan sesuatu/ apatis). Sedangkan informan lain dengan pola asuh orangtua yang galak dan cerewet (otoriter pattern of parenting), anak menjadi tidak bisa diam, selalu salah bila mengerjakan sesuatu, dan tidak memiliki kreativitas.

Orangtua dalam mendidik anak kurang sabar, pemarah, keras dan otoriter, adalah merupakan sumber stres yang dapat mempengaruhi kondisi kejiwaan anak dan remaja. Orangtua yang mampu menciptakan ikatan emosional kuat dengan anak akan lebih mudah membentuk karakter anak dan mengisinya dengan nilai-nilai yang baik. Maka untuk membentuk karakter anak dan mengisi anak dengan nilai-nilai yang baik, dibutuhkan ikatan emosional yang kuat antara orangtua dan anak. Hal ini dapat diperoleh melalui bentuk pola asuh yang diberikan oleh orangtua kepada anaknya. ${ }^{14}$

Penganiayaan efeknya pada perkembangan otak yang berkaitan dengan berbagai masalah psikologis, seperti depresi, masalah memori, kesulitan belajar, impusivitas, dan kesulitan dalam membina hubungan. ${ }^{15}$ Dari hasil penelitian didapatkan pengalaman traumatik informan yang menyebabkan informan mengalami gangguan jiwa skizofrenia adalah tindakan kekerasan yang dialaminya, di antaranya yaitu mendapat tindakan kekerasan dengan cara dipukul, dibanting, dan ditendang. Kasus ini banyak terjadi dalam keluarga (domestic violence). Domestic violence banyak menimpa wanita dan anak. Kondisi seperti ini merupakan stresor apabila tidak ditanggulangi segera maka akan menimbulkan gangguan jiwa. Sedangkan pada penelitian ini, faktor yang melatarbelakangi informan mengalami gangguan jiwa adalah akibat mendapat tindakan kekerasan fisik yang dialaminya. Kemungkinan Faktorfaktor yang dapat mempengaruhi terjadinya skizofrenia, antara lain: sejarah keluarga, tumbuh kembang di tengah-tengah kota, penyalahgunaan obat seperti amfetamin, stres yang berlebihan seperti mendapat seperti tindakan kekerasan baik fisik, emosional dan seksual, serta komplikasi kehamilan. ${ }^{16}$

\section{Daftar Pustaka}

1. Setiadi A. Skizofrenia memahami dinamika keluarga pasien. Bandung: PT Refika Aditama; 2006. 
2. Norwood SL. Research strategies for advanced practice nurses. New Jersey: Prentice Hill; 2005.

3. Moleong LJ. Metode penelitian kualitatif. Bandung: PT Remaja Rosdakarya; 2005.

4. Sugiyono. Memahami penelitian kualitatif. Bandung: ALFABETA; 2005.

5. Crotty M. Phenomenology and nursing research. Australia: Churchil; 2006.

6. Hawari. Pendekatan holistik pada skizofrenia. Jakarta: Gaya Baru publishing; 2005.

7. Soewadi. Ilmu kedokteran jiwa bahan kuliah kedokteran. Fakultas Kedokteran. Yogyakarta: Universitas Gajah Mada Press; 1990.

8. Videbeck SL. Psychiatric mental health nursing. Edisi ke-2. Philadelphia: Lippincott William and Wilkins publisher; 2004.

9. Stuart GW. Psychiatric nursing. Philadelphia: Mosby Prenty Hall; 2005.

10. Mega SJ. Pocket guide to psychiatric nursing.
Philadelphia: Mosby Prenty Hall; 2005.

11. American Psychiatric Association. Diagnostic and statistical manual of mental disorder-text revision. Edisi ke-4. Washington: American Psychiatric Association; 2000.

12. Eysenck MW, Psychology a student's handbook. 27 Church road UK: Psychology press Ltd. publisher; 2000.

13. Sadock K. Sinopsis psikiatri: pengetahuan prilaku psikiatri klinis. Edisi ke-7, jilid dua. Jakarta: Binarupa Aksara; 1997

14. Sadock BJ, Sadock VA. Synopsis of Psychiatry. Edisi ke-9. Philadhelpia: Lippincott Williams and Wilkins publisher; 2003.

15. Antai OD, Psychiatric nursing. Philadelphia: W.B. Company; 2005

16. Gestrude K. Psychiatric mental health nursing. Philadelphia: J.B. Lippincot Company; 2001. 